\title{
Democracy and National Security in Nigeria: A Discursive Exploration
}

\author{
Dr Atelhe, George Atelhe \\ Department of Political Science \\ Ahmadu Bello University, Zaria- Nigeria
}

\section{Doi:10.5901/mjss.2014.v5n4p495}

\begin{abstract}
This paper explores the nexus between democracy and national security in Nigeria. This is against the backdrop of the growing globally tenable optimism that holds that democracy is a desideratum for national progress and sustainability. By way of descriptive analysis of secondary sources, the paper posits that there is an integral and indispensable relationship between democracy and national security. Comprehending national security in terms of sustainable development, the paper argues that democracy in Nigeria should aspire towards leveraging potentials for sustainable national development in such a manner that guarantees enduring national sustainability.
\end{abstract}

\section{Introduction}

National security is the podium of democracy and if democracy loses security imperatives, it has lost its real substance (Abubakar, 2013). Chai Anan, the Thai political scientist, in his analysis of the role of the state in promoting democracy opined that the most important role of the state is in essence to ensure security for itself and for the people (Abubakar, 2013). A review of the traditionalist conception of national security reveals that the concept was conceived within a statecentric perspective (Alkali, 2003). This perception is increasingly becoming more of an anachronism, along with growing internal opposition to the hegemonic statist perception of national security; hence, the need for a re-think (Abubakar, 2013).

This paper contends that there is an integral relationship between democracy and national security and as such, national security has its essence in the sustenance of national security. In effect, even though military strategy still remains indispensable to national security, the crux of the contemporary national security question lies in broadening the notion of security to accommodate non-military considerations alongside more humane, equitable, and socially responsible practices by the state (Abubakar, 2013).

\section{Conceptualizing and Contextualizing Democracy}

Etymologically, the term 'democracy' was derived from two Greek root words namely demos (meaning people) and kratos/kratein (meaning rule). Simply put, therefore, democracy means people's rule or rule by the people. Democracy is one of the abiding legacies of the ancient Greek civilization in the contemporary world. It is often observed that the practice of democracy in its original form originated in Greece. This is not without any prejudice to the notion that comparable practices of democracy thrived in other places, even in Africa prior to Written History Okoli and Gusau, 2013).

In its original form, democracy meant a system of government based on the participation of all qualified citizens in decision-making (Renwick and Swinburn, 1980:151). There is no gainsaying the fact that conceiving democracy in terms of 'participation by all' is at best problematic. The complexities of modern society, adding to its huge population has made the practice of direct democracy unattainable. So, democracy today is understood in terms of representative government. In this indirect form, democracy depicts a political system in which the individual is involved in choosing a representative; usually from competing political parties (Renwick and Swinburn, 1980).

Indirect/ representative democracy thrives on the principle of representation. This enables the people to choose those who will represent their interest in public decision- making. The expectation is that those occupying positions of public role in a democracy do so at the instance of the people, whose delegated mandate they hold in civic trust (Okoli and Gusau, 2013).

Democracy is built on certain principles, prominent among which are outlined and discussed below.

1. Popular Sovereignty: - This means that the supreme power to rule rests with the people (the electorate). The 
people decide who rules them and under what party or ideological platform. They also hold the authority to change the government in case it fails to live up to expectation (Okoli and Gusau, 2013).

2. Popular Representation:- As indicated above, the elected government officials hold their mandate at the instance of the people. They are in such position to represent the interest of their people. Popular representation entails the ability of the political representative to serve the interests of his people (constituency) properly. It entails being in touch with the people and timely consultation of one's constituency given matters affecting their interest (Okoli and Gusau, 2013).

3. Popular Participation: - Without any prejudice to legally tenable limitations to franchise, the expectations in a democracy is that everybody participates in the process of governance. In effect, all citizens are equally stakeholders in the business of governance. Popular participation implies being active in the political process, whether at the leadership or followership level (Renwick and Swinburn, 1980).

4. Rule of Law: - This means supremacy as well universal applicability of the law. In a democracy, the dictates of the regular law must prevail in all circumstances in such a manner that forecloses impunity, arbitrariness and abuse (Okoli and Okpaleke, 2013). The law should not be a respecter of individuals no matter one's status or dignity. The 'sacred cow syndrome' and 'double standards' in the application of the law is shunned. In effect, no one is above the law and no one should be seen to be so.

5. Civil Liberty: - Democracy guarantees basic freedoms and institutionalizes mechanisms for actualizing them. It also puts in place procedures for seeking redress in the event of any violation of these entitlements. In fact, the place of civil rights in a democracy is sacrosanct and pivotal. Some of these rights include: right to life, right to property, freedom to speech, freedom to the press, etc (Okoli and Gusau, 2013).

6. Other Relevant Principles:- These include the following:
i. Equity
ii. Justice
iii. Civility
iv. Accountability
v. Transparency, etc.

Democracy has become so much entrenched in the modern world. Note, however, that democracy has been categorized as either liberal or radical. Liberal democracy is the essence of the present world order. It is subscribed to many nations, even though there have been copious variations from the orthodox model. Radical democracy is often referred to as socialist democracy. It seeks to re-construct the society based on socialist ideals and principles. Cases in point include the communist Russia and China (Okoli and Gusau, 2013).

By way of overview, democracy presupposes a political system in which the people of a country rule through any form of government they choose to establish. In modern democracies, supreme authority is exercised for the most part by representatives elected by popular suffrage. The representatives may be supplanted by the electorate according to the legal procedures of recall and referendum, and they are, at least in principle, responsible to the electorate (Encarta Premium DVD, 2009). In many democracies, such as the United States, both the executive head of government and the legislature are elected. In typical constitutional monarchies such as the United Kingdom and Norway, only the legislators are elected, and from their ranks a cabinet and a prime minister are chosen (Encarta Premium DVD, 2009).

Although often used interchangeably, the terms democracy and republic are not synonymous. Both systems delegate the power to govern to their elected representatives. In a republic, however, these officials are expected to act on their own best judgment of the needs and interests of the country. The officials in a democracy more generally and directly reflect the known or ascertained views of their constituents, sometimes subordinating their own judgment (Encarta Premium DVD, 2009).

\subsection{Global Trend of Democracy and Democratization}

According to Okoli and Okpaleke (2013: 1), "democracy, indeed, has become the most dominant political movement in the world today". The popularity of this political practice has been a worldwide trend over the years. In effect, by the second half of the $20^{\text {th }}$ century, most independent states in the world had a government that more or less embodied some of the tenets of democracy (Okoli and Okpaleke, 2013: 1).

Since the demise of the Cold War in the early 1990s and, of course, the advent of globalization proper thereafter, the world has witnessed radical waves of democratization whereby some notorious dictatorial regimes gave way for democratic change (Odofin and Omojuwa, 2007). And with the coming of the Arab Spring in the late 2010 and early 
2011, the global wave of democracy has come a full cycle.

The recrudescence of democratic censoriousness and movement around the world today presupposes the fact that democracy has been entrenched globally as the ultimate model of governance. In this respect, the expectation is that nations should key into this governance paradigm, else they could as well relapse into political atavism of old (Okoli and Okpaleke, 2013: 1).

The liberal trend spread to some nations in Africa in the 1990s, most prominently in South Africa. Some recent examples of attempts of liberalization include the Indonesian Revolution of 1998, the Bulldozer Revolution in Yugoslavia, the Rose Revolution in Georgia, the Orange Revolution in Ukraine, the Cedar Revolution in Lebanon, the Tulip Revolution in Kyrgyzstan, and the Jasmine Revolution in Tunisia (Wikipedia, 2013).

According to Freedom House, in 2007 there were 123 electoral democracies (up from 40 in 1972 (Freedom House, 2004/2007). According to World Forum on Democracy, electoral democracies now represent 120 of the 192 existing countries and constitute 58.2 percent of the world's population. At the same time liberal democracies - those regarded as free and respectful of basic human rights and the rule of law - are 85 in number and represent 38 percent of the global population (Wikipedia, 2013). The following countries are categorized by the Democracy Index 2012 as Full democracy:

Box1: World's Full Democracy at 2007

\begin{tabular}{|lllll|}
\hline 1.Norway & 11. Luxembourg & 6.Australia 16. & United Kingdom & 21. United States \\
2.Sweden & 12. Austria & 7. Switzerland & 17. Czech Republic & 22. Costa Rica \\
3.Iceland & 13. Ireland & 8. Canada & 18. Uruguay & 23. Japan \\
4.Denmark & 14. Germany & 9. Finland & 19. Mauritius & 24. Belgium \\
5.New Zealand & 15. Malta & 10. Netherlands & 20. South Korea & 25. Spain \\
\hline
\end{tabular}

Source: Wikipedia (2013).

The Democracy Index also assigns 53 countries to the lower category, Flawed democracy: Argentina, Benin, Botswana, Brazil, Bulgaria, Cape Verde, Chile, Colombia, Croatia, Cyprus, Dominican Republic, El Salvador, Estonia, France, Ghana, Greece, Guyana, Hungary, Indonesia, India, Israel, Italy, Jamaica, Latvia, Lesotho, Lithuania, Macedonia, Malaysia, Mali, Mexico, Moldova, Mongolia, Montenegro, Namibia, Panama, Papua New Guinea, Paraguay, Peru, Philippines, Poland, Portugal, Indonesia, Romania, Serbia, Slovakia, Slovenia, South Africa, Sri Lanka, Suriname, Taiwan, Thailand, Timor-Leste, Trinidad and Tobago, Zambia (Wikipedia, 2013).

\title{
3. Democracy and National Security in Nigeria
}

In this paper, the conception of national security aligns with the revisionist perspective. As observed by McNamara (1968:149):

\begin{abstract}
In a modernizing society, security means development. Security is not military force though it may involve it. Security is not traditional military activity though it may encompass it. Security is not military hardware though it may include it. Security is development and without development, there can be no security.
\end{abstract}

To say the least, national security means sustainable development whereof the nation enjoys freedom from poverty, ignorance, disease, and other forms of vulnerability (Okoli, 2013). In the light of the foregoing perspective, it has been observed by scholars that there is a nexus between democracy and development. For the average Nigerian, democracy is only meaningful if it delivers what has become known as democracy dividends i.e. socio-economic development. It has also been argued that there is an organic linkage between the political freedom that can be brought about by democracy and freedom from hunger, ignorance and disease that can come from socio-economic development (Igbuzor, 2005). The latter refers to the fundamentals of national security based on the standpoint of this paper,

In the light of the foregoing, democracy is often, but rightly, considered a precondition for sustainable development. Agenda 21, the United Nations 1992 action plan on sustainable development, proclaims that "sustainable development requires [...] progress towards democratic government." Hence, Swedish professor Peter Söderbaum has advanced the argument that the transparency that accompanies democracy improves the prospects for sustainable development. Indeed, the notion that democracy is necessary for sustainable development is a plausible one. Both are 
often seen as admirable qualities of free and just and progressive societies. Indeed, the two might be seen as mutually reinforcing Igbuzor, 2005).

There are certain themes that should punctuate our understanding of democracy. First, a lot of emphasis should be placed on the kind of governance that can bring about true democracy and development (Igbuzor, 2005). One way of coming to terms with this is to consider the extent to which democracy is bringing about the so-called development deliverables, or better put, dividends of democracy. Dividends of democracy refer to the material gains of the democratic practice. It is a highly subjective political concept that has been variously applied to mean:

i. accelerated infrastructural development,

ii. economic recovery,

iii. health and job creation,

iv. human empowerment,

v. poverty alleviation/eradication,

vi. greater access to efficient Medicare and education,

vii. sustainable safety and security, etc.

The question is what has been happening to the aforementioned sectors since the latest return of democracy in Nigeria in 1999? Has Nigeria really recorded any appreciable transformation with respect to the above? For instance, with reference to the issue of security which is a core value of governance in a democracy, Nigeria has been worse off since 1999. There have been rising waves of security volatility and violence manifesting in the following forms:

i. the Niger Delta crisis (1999-2009),

ii. spate of ethno-religious crises in parts of Northern Nigeria

iii. ethnic violence and communual clashes in North-central States of Plateau, Nasarawa, Taraba and Benue

iv. electoral violence of $1999,2003,2007$ and 2011 polls,

$\mathrm{V}$. the growing prevalence of kidnapping, especially in Southern Nigeria

vi. the Islamist uprising orchestrated by the 'Boko Haram' sect since 2009, etc (Okoli and Okpaleke, 2013).

Apart from the issue of security, government has equally not fared very well in the areas of human development. Hence, there is rising incidence of poverty, unemployment, livelihood crisis, humanitarian crisis, illiteracy, disease, malnutrition, and the likes. The contention of this paper is that decades of democratic practice in Nigeria has not delivered the country from vulnerabilities arising from the aforementioned threats. In effect, despite the popular expectation that democracy would leverage the potential for accelerated national transformation and security, Nigerians are yet to have a tangible feel of real democracy dividends. Worse still, there appears to be a continued degeneration of corruption and impunity in Nigeria. This is evident in the conduct of the political class whose attitude in power has impeded the realization of good governance in the country.

So, if democracy is expected to bring about sustainable national development and security as this paper has argued, the verdict in respect of Nigeria is therefore hopeless. His is in view of the fact that, contrary to popular expectation, democracy in Nigeria has largely failed to free the country from poverty, hunger, ignorance, preventable disease, disaster, violence conflict and other forms of vulnerabilities. This implies that democracy in Nigeria is yet to deliver the ultimate good: guaranteeing sustainable national security.

\section{Conclusion}

This paper set out to explore the nexus between democracy and national security. This is against the backdrop of the globally tenable expectation that democracy is a desideratum for sustainable societal progress and sustainability. Conceptualizing national security in terms of sustainable development, the paper argued that democracy is worth nothing if it does not deliver the good of sustainable societal development. Hence, it was argued that democracy must justify its practice by leveraging opportunities for societal development, particularly in the areas of mitigating the surge of poverty, ignorance, disease, disaster, violent conflicts, and the likes. The paper observed that democracy in Nigeria has so far failed to produce the expected outcome in this direction. The worsening trends of insecurity and development malaise in contemporary Nigeria suggest that democracy in the country has left much to be desired. The way forward in this regard is to revitalize the practice of democracy in the country in such a manner that would leverage the potentials for good governance and national sustainability. This is the ultimate challenge to democracy and democratization in Nigeria. 


\section{References}

Freedom House (2004/2007). "World's Electoral Democracies"; http://www.freedomhouse.org

Wikipedia (2013). "Table and Charts: Electoral Democracies"; http://foredemocracy.net

United Nations (2010). "General Assemmly declares September 15 International Day of Democracy"; http://www.un.org

Wikipedia (2013). "Democracy Index, 2012: Democracy at a Standstill"; http:enwikipedia.org/wiki/Democracy\#cite_ref-di2012_61-0

Wikipedia (2013). "Democracy Index 2012: Democracy under Stress"; http://enwikipedia.org/wiki/Democracy\#cite_ref-63

Igbuzor, O (2005). "Perspectives on Democracy and Development in Nigeria"; http///c:/users/josh/Desktop/perspectives on Democracy and Development.htm

Okoli, A.C. (2013). "The Dialectics of the Niger Delta Crisis: A Political Ecology Interpretation". Niger Delta Research Digest, 7(1), pp.6389.

Okoli. A. C. and Orinya, S. (2013). "Oil Pipeline Vandalism and Nigeria's National Security". Global Journal of Human Social Sciences: F (Political Science), 13(5:1:0), pp.67-75.

Okoli, A.C. and Gusau, A.S. (2013). "Political Ideas". Lecture Mimeograph, Department of Political Science, Federal University Lafia, Nigeria.

Encarta (2009, DVD). Encarta Student Encyclopedia, 2009 Premium DVD Version. Encarta Corporation.

Okoli, A. C. and Okpaleke, N. F. (2013). "Federalism in Nigeria: Some Reflections". NASHER Journal of Multidisciplinary Research (forthcoming).

Abubakar, A.N. 9201). "Democracy and National Security in Nigeria". The selected Works of Ali Nuhu Abubakar: available at http://works.bepress.co/ali_abubakar/1

Alkali, R. (2013). Issues in International Relations and Nigerian Foreign Policy.Kaduna: North-point Publishers.

Odofin, A.P and Omojuwa, K.A. (2007). The Challenges of the Democratization Process in Nigeria. Zaria: A-Y Sule Digital Printers.

Renwick, A. and Swinburn, I. (1980). Basic Political Concepts. London: Hutchinson. McNamara, R. S. (1968). The Essence of Security: Reflections in Office. New York: Harper and Row. 